\title{
Glioma gene therapy with soluble transforming growth factor-ß receptors II and III
}

\author{
ULRIKE NAUMANN $^{1}$, PHILIPP MAASS ${ }^{1,2}$, ANNE-KATHRIN GLESKE ${ }^{1,3}$, \\ STEFFEN AULWURM ${ }^{1,4}$, MICHAEL WELLER ${ }^{1,5}$ and GUENTER EISELE ${ }^{1,5}$ \\ ${ }^{1}$ Department of General Neurology, Hertie Institute for Clinical Brain Research, \\ University of Tuebingen, Tuebingen, Germany
}

Received May 5, 2008; Accepted June 27, 2008

DOI: 10.3892/ijo_00000062

\begin{abstract}
Transforming growth factor- $\beta$ (TGF- $\beta$ ) is abundantly expressed in malignant gliomas and is crucial for the tumor micromilieu. TGF- $\beta$ not only enhances migration and invasion of glioma cells but also inhibits an effective anti-glioma immune response. TGF- $\beta$ mediates its biologic effects through interactions with TGF- $\beta$ receptors (TßR)-I to -III. Binding of TGF- $\beta$ leads to the activation of an intracellular signaling cascade and subsequent phosphorylation of Sma and MADrelated proteins (SMAD). Soluble TGF- $\beta$ receptors (TßRs) abrogate the TGF- $\beta$ effect by competing for the binding of the ligand to its receptor. Here we used adenoviral gene transfer to express TßR-IIs and -IIIs in human glioma cell lines. TßR-IIs reduced SMAD2 phosphorylation and TGF- $\beta$-dependent reporter activity. Furthermore, it enhanced glioma cell lysis by natural killer cells. TßR-IIIs alone were inactive in these assays, but enhanced the effects of TßR-IIs. Transduction of LN-308 cells with TßRs markedly delayed growth of intracerebral xenografts in nude mice in vivo. These data commend TßRs for possible experimental therapy of gliomas.
\end{abstract}

\section{Introduction}

Gliomas are highly malignant intrinsic brain tumors. Overexpression of TGF- $\beta$ is a typical feature of gliomas in vitro

Correspondence to: Dr Ulrike Naumann, Department of General Neurology, Hertie Institute for Clinical Brain Research, OtfriedMüller Strasse 27, D-72076 Tuebingen, Germany

E-mail: ulrike.naumann@uni-tuebingen.de

Present addresses: ${ }^{2}$ Max-Delbrück Center, Robert-Rössle-Str. 10, D-13125 Berlin; ${ }^{3}$ Institute for Medical Microbiology, ElfriedeAulhorn-Str. 6, D-72076 Tuebingen; ${ }^{4}$ Institute of Immunology, University of Tuebingen, Auf der Morgenstelle 15, D-72076 Tuebingen, Germany; ${ }^{5}$ Department of Neurology, University Hospital Zürich, Frauenklinikstrasse 26, CH-8091 Zürich, Switzerland

Key words: TGF- $\beta$, adenovirus, natural killer cell, glioma, gene therapy and in vivo. Elevated concentrations of TGF- $\beta$ are detectable in glioma cyst fluids and in the cerebrospinal fluid of glioma patients (1). TGF- $\beta$ plays a key role in malignant glioma progression. It blocks the activation of immune cells via downregulation of immunoactivating ligands on glioma cells and induces apoptosis of $\mathrm{T}$ and natural killer (NK) cells $(2,3)$. To note, TGF- $\beta$ is upregulated with increasing grade of glioma malignancy $(4,5)$.

The TGF- $\beta$ receptor signaling cascade consists of a variety of different proteins. Three receptors with a different affinity to TGF- $\beta$ subtype $-1,-2$ and -3 have been characterized so far and named type I (TßR-I), type II (TßR-II) and type III (TßR-III/betaglycan). TßR-I and TßR-II are transmembrane proteins with serine/threonine kinase function (6). Membranebound TBR-III has no kinase activity and may function to enrich and to present TGF- $\beta$ to the signaling complex (7). Once TGF- $\beta$ binds to TßR-II, TßR-I is phosphorylated by TßR-II and propagates the signal via phosphorylation of SMAD proteins which leads to the regulation of a variety of genes.

Antagonizing TGF- $\beta$ is a promising strategy to counteract malignant properties of tumors (8). Several approaches have been developed such as small molecule inhibitors (9), antisense strategies (10) or soluble TGF- $\beta$ receptors. TGF- $\beta$ neutralizing effects and subsequent anti-tumor activity have been described upon expression of TßR-IIs or TßR-IIIs in a variety of cell lines and animal tumor models for pancreatic, prostate or breast cancer and malignant mesothelioma (11-14). In a rat gliosarcoma model, TßR-IIs led to enhanced immunogenicity of the tumors and enhanced survival (15). These data along with the prominent role of TGF- $\beta$ in glioma prompted us to assess whether TßR-IIs or TßR-IIIs are putative candidate therapeutic agents for glioma.

\section{Materials and methods}

Cell lines and reagents. U87MG, LNT-229 and LN-308, human malignant glioma cell lines, were kindly provided by N. de Tribolet (Lausanne, Switzerland). CCL64 mink lung epithelial cells and MLEC32, a mink epithelial lung cell line stably transfected with an 800-bp fragment of the human plasminogen activator inhibitor-1 (PAI-1) gene fused to the firefly luciferase (Luc) reporter gene in a p19Luc-neo vector, were a kind gift from D. Rifkin (New York, NY, USA). All 
cell lines were maintained in Dulbecco's modified Eagle's medium (DMEM, Lonza, Basel, Switzerland) containing $10 \%$ fetal calf serum (FCS), glutamine $(2 \mathrm{mM})$, penicillin $(100 \mathrm{IU} / \mathrm{ml}) /$ streptomycin $(100 \mu \mathrm{g} / \mathrm{ml})$ and the appropriate antibiotics. CD56-positive human NK cells were prepared from peripheral blood monocytic cells using an indirect magnetic labeling system (Miltenyi Biotec, Bergisch Gladbach, Germany). SD-208 is a selective TßR-I kinase inhibitor kindly provided by Scios Inc. (Freemont, CA, USA) (9). Recombinant human TGF- $\beta_{2}\left(\right.$ rhTGF$\left._{2}\right)$ was purchased from Peprotech Inc. (Hamburg, Germany).

Construction of adenoviral vectors and infection procedure. Ad-LacZ, Ad-eGFP and Ad- $\Delta \mathrm{E} 1$ have been previously described (16). Ad-TßR-IIs encode the extracellular domain of the TGF- $\beta$ receptor type II, fused to a human Fc peptide (17). For the generation of Ad-TßR-IIIs, the extracellular domain of the human TßR-III was amplified by PCR from pBLUE-TßR-III (18) using the forward primer TTT GTC GAC ATG ACT TCC CAT TAT GTG ATT GCC and the reverse primer TTT AAG CTT TAA GTC CAG ACC ATG GAA AAT TGG TGG. The PCR fragment was cloned into pCRII, completely sequenced, compared to the NCBI database and was found to be correct (GenBank accession no. NM003243). Thereon the fragment was cloned into pTRACKCMV using the Ad-Easy system provided by B. Vogelstein (Baltimore, MD, USA). Ad-TßR-III additionally codes for eGFP in a second expression cassette. Recombinant adenoviral genomes were transfected into HEK-293 cells (ATCC). The virus was purified and titrated according to standard procedures $(16,19)$. Transgene expression and secretion were verified by immunoblotting. Infection with recombinant viruses was accomplished by exposing cells to different concentrations of adenovirus in serum-free DMEM for 15 min followed by the addition of serum-containing medium for 1-5 days. If cells were double infected, total moiety of infection (MOI) as well as eGFP expression was set equal by adding either Ad-LacZ or Ad-eGFP.

Generation of cellular supernatants containing T $\beta R$ s. For the generation of supernatants, the cells were infected with the appropriate concentration of virus. Six hours after infection, the cells were washed twice with serum-free medium (SFM), and SFM was added for 24-48 h. Supernatants were harvested and cleared from cellular debris by centrifugation. Secreted proteins were assessed by immunoblotting. Supernatants were stored at $-80^{\circ} \mathrm{C}$ for further use.

Growth and viability assays. Net cell culture growth was determined by crystal violet staining. Briefly, the cells were stained with crystal violet for 10 min followed by several washes with tap water. Bound crystal violet was dissolved in $50 \%$ ethanol/0.1 M sodium citrate, and optical density readings were obtained using an ELISA reader (Thermo Electron Multiskan EX) at $560 \mathrm{~nm}$. To assess viability, the cells were trypsinized and stained with trypan blue.

Immunoblot analysis. The general procedure has been previously described (16). The following antibodies were used: anti-TßR-II (SC1700, Santa Cruz Biotechnology, Santa
Cruz, CA, USA), anti-TßR-III (AF-242-PB, R\&D Systems, Wiesbaden, Germany), anti- $\beta$-actin (SC-1616, Santa Cruz), anti-phospho-SMAD2 (\#3108, Cell Signaling, Danvers, MA, USA) and anti-SMAD2/3 (BD Biosciences, Aalst, Belgium).

Luciferase reporter assay. Cells were seeded in triplets in microtiter plates and transfected with 150 ng pGL3-TP3Luc, expressing firefly luciferase under the control of an artificial TGF- $\beta$-inducible promoter, and $20 \mathrm{ng}$ pRL-CMV as an internal standard. At $48 \mathrm{~h}$ after transfection, the cells were incubated with supernatants of glioma cells expressing TßRs in the absence or presence of rhTGF $_{2}$. To allow complex formation between TGF- $\beta$ and soluble receptors, mixtures were preincubated for $30 \mathrm{~min}$ at room temperature before adding to the transfected cells. TGF- $\$$-mediated luciferase activity was assessed as previously described (9).

NK lysis assay. To measure the lytic activity of human CD56positive NK cells, they were incubated for $24 \mathrm{~h}$ with supernatants of virus-infected glioma cells secreting TßRs and a parallel addition of $\mathrm{rhTGF}_{2}(1 \mathrm{ng} / \mathrm{ml})$ or vehicle. To allow complex formation, rhTGF$_{2}$ and supernatants were preincubated for $30 \mathrm{~min}$ at room temperature. A standard ${ }^{51} \mathrm{Cr}$ release assay was performed using $2000{ }^{51} \mathrm{Cr}$-labeled LNT-229 target cells/well. Effector (E) and target (T) cells were incubated at various E:T ratios for $4 \mathrm{~h}$.

Glioma/NK cell coculture. For coculture of TßR-expressing glioma cells and NK cells, LN-308 cells were infected with $150 \mathrm{MOI}$ of the appropriate virus for $24 \mathrm{~h}$ followed by irradiation with $30 \mathrm{~Gy}$ to block proliferation. After irradiation, CD56-positive human NK cells were added. Lysis of eGFPpositive glioma cells was assessed optically at $21 \mathrm{~h}$ after coculture.

Animal studies. CD1 nu/nu mice (Charles River, Sulzfeld, Germany) were anesthetized and placed in a stereotactic fixation device (Stoelting, Wood Dale, IL, USA). LN-308 cells $\left(1 \times 10^{5}\right)$, infected with 150 MOI of the appropriate virus $6 \mathrm{~h}$ prior to inoculation, were injected into the right striatum. The mice were sacrificed when developing neurological symptoms. All animal research was carried out in accordance with the law for treatment of animals in Germany and approved by the local authorities (N3/03, Regierungspräsidium Tuebingen, Germany).

\section{Results}

Expression and toxicity of TßRs in glioma cell lines. We first analyzed the expression and secretion of adenovirally encoded TßR-IIs and TßR-IIIs. LNT-229, LN-308 or U87MG cells were infected with increasing MOI of Ad-LacZ, Ad-TßR-IIs or Ad-TßR-IIIs. TßRs were expressed in all tested cell lines as analyzed by RT-PCR and by immunoblotting of cellular lysates (data not shown). To ascertain that TßRs were secreted from infected cells, cellular supernatants were studied by immunoblotting (Fig. 1A and B). Protein levels depended on the cell line and MOI. At $48 \mathrm{~h}$ after infection, accumulation of TßR-IIs in supernatants was high in all cell lines when using at least $100 \mathrm{MOI}$ of adenovirus. For TßR-IIIs, secretion was 
A

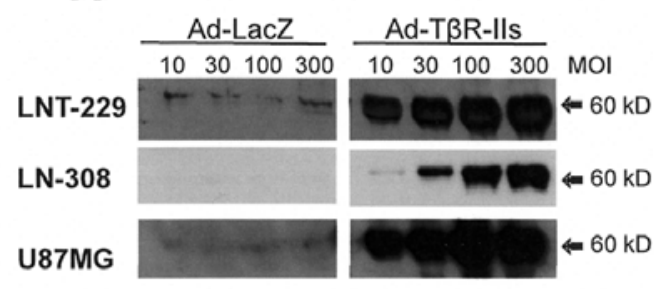

B

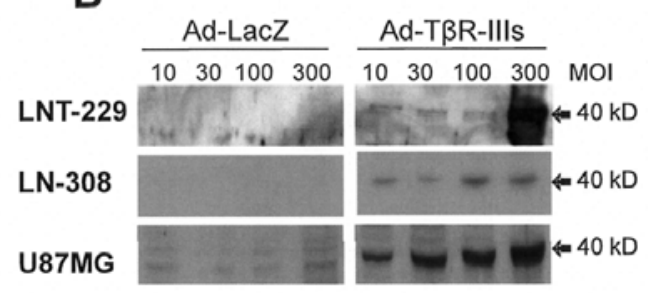

C

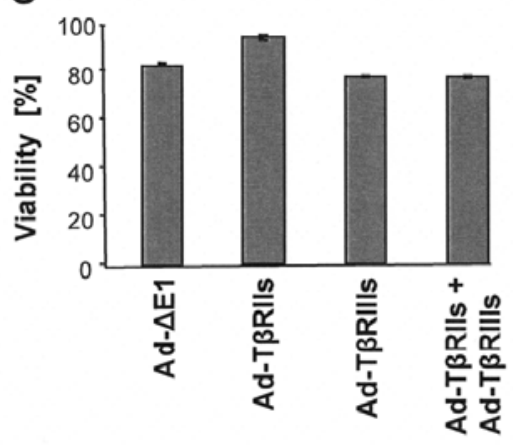

Figure 1. Secretion of TßRs in glioma cell lines. LNT-229, LN-308 or U87MG glioma cells $\left(1 \times 10^{6}\right)$ were infected with 10-300 MOI of Ad-LacZ, Ad-TßR-IIs (A) or Ad-TßR-IIIs (B). At $6 \mathrm{~h}$ after infection, the cells were washed and SFM was added. Supernatants were harvested $48 \mathrm{~h}$ later, and secretion of TßRs was assessed by immunoblotting using antibodies to TßR-IIs (A) or TßR-IIIs (B) (notice the presence of an unspecific protein band in Ad-LacZ-infected cells when using a TßR-II-specific antibody. (C) LN-308 cells were infected with either $300 \mathrm{MOI}$ of Ad- $\Delta \mathrm{E} 1$, Ad-TßR-IIs, Ad-TßRIIIs or both. Viability was assessed after $48 \mathrm{~h}$ of infection $(n=3, S D$; one representative experiment is shown).

highest in U87MG and low to moderate in LN-308 and LNT-229 cells. To rule out weak transduction efficiency of Ad-TßR-IIIs, we analyzed if the adenoviral infection was successful. Using 100 MOI of Ad-eGFP or Ad-TßR-IIIs, $>95 \%$ of the cells were eGFP-positive (data not shown). We therefore used $\geq 100$ MOI for further experiments.

The influence of viral infection on cell proliferation and viability was assessed in parallel. Only a marginal amount of cell death and inhibition of proliferation was detected at 300 MOI of Ad- $\triangle \mathrm{E} 1$, Ad-TßR-IIs, Ad-TßR-IIIs or both AdTßR-IIs and Ad-TßR-IIIs. No cell death was detected using $<200$ MOI of adenovirus (Fig. 1C for cell line LN-308 and data not shown).

TßRs are functionally active. To assess if TßR-IIs or TßR-IIIs alone or in combination compete for the binding of TGF- $\beta$ to cell surface TGF- $\beta$ receptors, LNT-229 cells were infected with Ad-LacZ, Ad-TßR-IIs, Ad-TßR-IIIs alone or in combination. At $24 \mathrm{~h}$ after infection, $\mathrm{rhTGF}_{2}$ was added and
SMAD2 phosphorylation was assessed. Phosphorylated SMAD2 (P-SMAD2) was reduced in Ad-TßR-II-infected, but not in control or Ad-TßR-III-infected LNT-229 cells. PSMAD2 was decreased to lowest levels in the cells doubleinfected with Ad-TßR-IIs and Ad-TßR-IIIs (Fig. 2A). We next analyzed the influence of TßR-IIs and TßR-IIIs on the expression of TGF-ß-responsive genes. The cell line U87MG was chosen for this assay because of the lowest expression levels of endogenous TGF- $\beta_{1}$ and $-\beta_{2}$. U87MG cells were infected with Ad-LacZ, Ad-TßR-IIs, Ad-TßR-IIIs or both. Supernatants were harvested, pre-incubated with $\operatorname{rhTGF}_{2}$ and added to LNT-229 glioma cells transiently transfected with a TGF- 3 -responsive reporter construct. rhTGF $_{2}$, pre-incubated with supernatant from uninfected or control virus-infected cells, induced reporter gene activity. This activation was repressed when rhTGFß $\beta_{2}$ was pre-incubated with supernatants of TßR-II-expressing cells, but not with supernatants of TßR-III-infected cells. Complete repression of TGF- 3 -induced reporter gene activity was detected when $\operatorname{rhTGF} \beta_{2}$ was preincubated with supernatant of Ad-TßR-II and Ad-TßR-III double-infected cells (Fig. 2B).

The functional activity of TßRs was also assessed in CCL64 cells (data not shown) and in MLEC32 cells (Fig. 2C), a TGF- $\beta$-sensitive mink lung epithelial cell line stably transfected with a TGF- $\beta$-dependent reporter construct expressing the firefly luciferase under control of the PAI-1 promoter. Again, supernatants of LNT-229 glioma cells containing TßR-IIs and TßR-IIIs reversed the antiproliferative effect in CCL64 cells (data not shown) as well as TGF- $\beta$ induced reporter gene activity of exogenous added $\mathrm{rhTGF}_{2}$ in MLEC32 cells (Fig. 2C). Expression of sTßR in the supernatants was confirmed by immunoblotting (data not shown).

Expression of T及Rs blocks the immunosuppressive effect of $T G F-\beta$ on NK cells. TßRs might block the immunosuppressive effects mediated by TGF- $\beta$ on NK cells. In the first assay, LN308 glioma cells were cocultured with NK cells. The cell line LN-308 was selected because of the secretion of large amounts of TGF- $\beta_{1}$ and $-\beta_{2}$. The cells were infected with AdLacZ, Ad-TßR-IIs, Ad-TßR-IIIs or both Ad-TßR-IIs + AdTßR-IIIs. To uniformly label the glioma cells with eGFP and to equalize MOI of infection, the cells were coinfected with either Ad-eGFP or Ad-LacZ. To avoid further proliferation of glioma cells, the cells were irradiated $24 \mathrm{~h}$ after infection and then coincubated with freshly isolated human NK cells. Approximately $90 \%$ of Ad-TßR-II-infected glioma cells were eradicated at $21 \mathrm{~h}$ after coculture, whereas no such effect was observed with control or Ad-TßR-III-infected glioma cells (Fig. 3A), indicating a rescuing effect of TßR-IIs on the lytic capabilities of NK cells towards the glioma cells. To determine the extent of NK cell-specific glioma cell lysis, human NK cells were cultured in normal medium or supernatants of LNT-229 cells infected with Ad-LacZ or Ad-TßR-IIs and Ad-TßR-IIIs supplemented with vehicle or rhTGFß $\beta_{2}$. The NK cells were subsequently used as effectors in a standard ${ }^{51} \mathrm{Cr}$ release assay with untreated LNT-229 cells as targets. As expected, addition of rhTGFß ${ }_{2}$ to control NK cells or to NK cells cultured in supernatant of control virus-infected LNT-229 

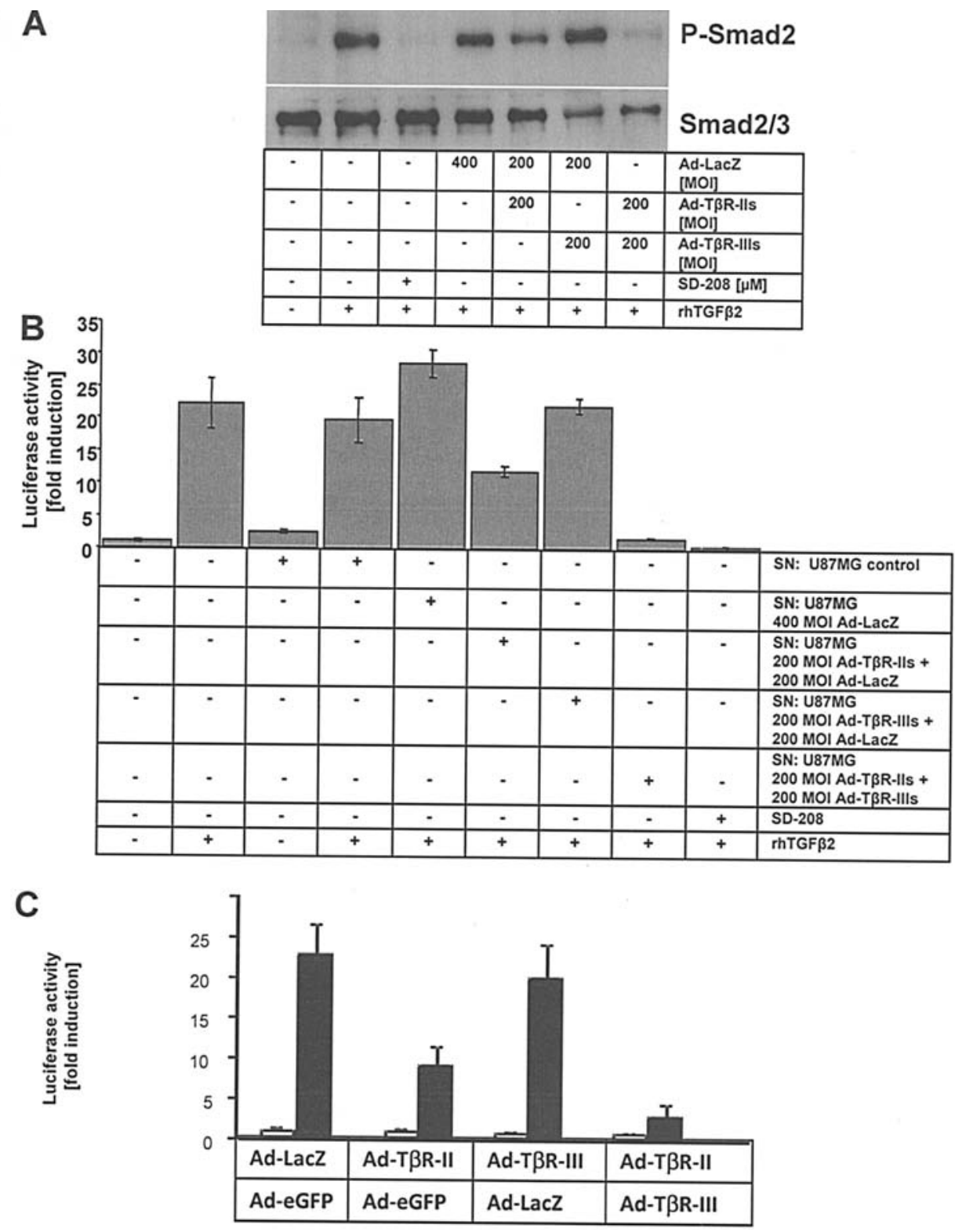

Figure 2. Expression of TßRs inhibits TGF-ß signaling. (A) LNT-229 cells were infected with Ad-LacZ, Ad-TßR-IIs, Ad-TßR-IIIs or both. At $6 \mathrm{~h}$ after infection, the cells were washed, and SFM was added. At $36 \mathrm{~h}$ after infection, $\mathrm{rhTGF}_{2}(10 \mathrm{ng} / \mathrm{ml})$ or vehicle was added for 15 min. Phosphorylation of SMAD2 was assessed by immunoblotting. (B) LNT-229 cells were seeded in triplets and transfected with pGL2-3TP-Luc and pRL-CMV. At $48 \mathrm{~h}$ after transfection, supernatants of infected U87MG cells (200 MOI of each virus, $48 \mathrm{~h}$ in SFM), either preincubated with $\mathrm{rhTGF} \mathrm{B}_{2}(10 \mathrm{ng} / \mathrm{ml})$ or vehicle for $30 \mathrm{~min}$, were added. As a control, LNT-229 cells were pretreated with SD-208. At $24 \mathrm{~h}$ after incubation, reporter gene activity was analyzed (n=2, SD, one representative experiment is shown). (C) Supernatants of Ad-Virus-infected LNT-229 glioma cells (200 MOI for each virus, 48 h) were incubated with $\mathrm{rhTGF}_{2}(10 \mathrm{ng} / \mathrm{ml}$, black bars) or vehicle (white bars) for $30 \mathrm{~min}$. Preincubated supernatants were added to MLEC32 cells. TGF-ß-mediated luciferase activity was assessed after an additional $24 \mathrm{~h}(\mathrm{n}=2 ; \mathrm{SD}$, one representative experiment is shown).

cells attenuated the lytic capabilities of these NK cells. Again, the immunosuppressive effect of $\mathrm{rhTGF}_{2}$ was reverted when the NK cells were cultured with supernatants containing TBRs (Fig. 3B). Therefore, TßRs might be able to restore an effective anti-glioma immune response by neutralizing TGF- $\beta$.

Expression of T及Rs prolongs survival of glioma-bearing mice. To assess a function of TßRs in vivo, LN-308 glioma cells infected either with Ad-LacZ, Ad-TßR-IIs, Ad-TßR-IIIs or both were implanted into the right striatum of nude mice. Survival was assessed in a Kaplan-Meier analysis (Fig. 4). In this experiment, mice receiving a tumor expressing TBR-IIs alone or in combination with TßR-IIIs showed a markedly prolonged survival. Expression of TBR-IIIs alone had no significant effect on prolongation of survival. This is consistent with the in vitro data, already indicating a superior effect of TßR-IIs compared to TßR-IIIs.

\section{Discussion}

The present study sought to determine the possible value of TßRs as therapeutic agents for malignant gliomas. We showed that adenovirus infection of glioma cells leads to production of TßRs (Fig. 1A and B). TßR-IIs and -IIIs showed 
A
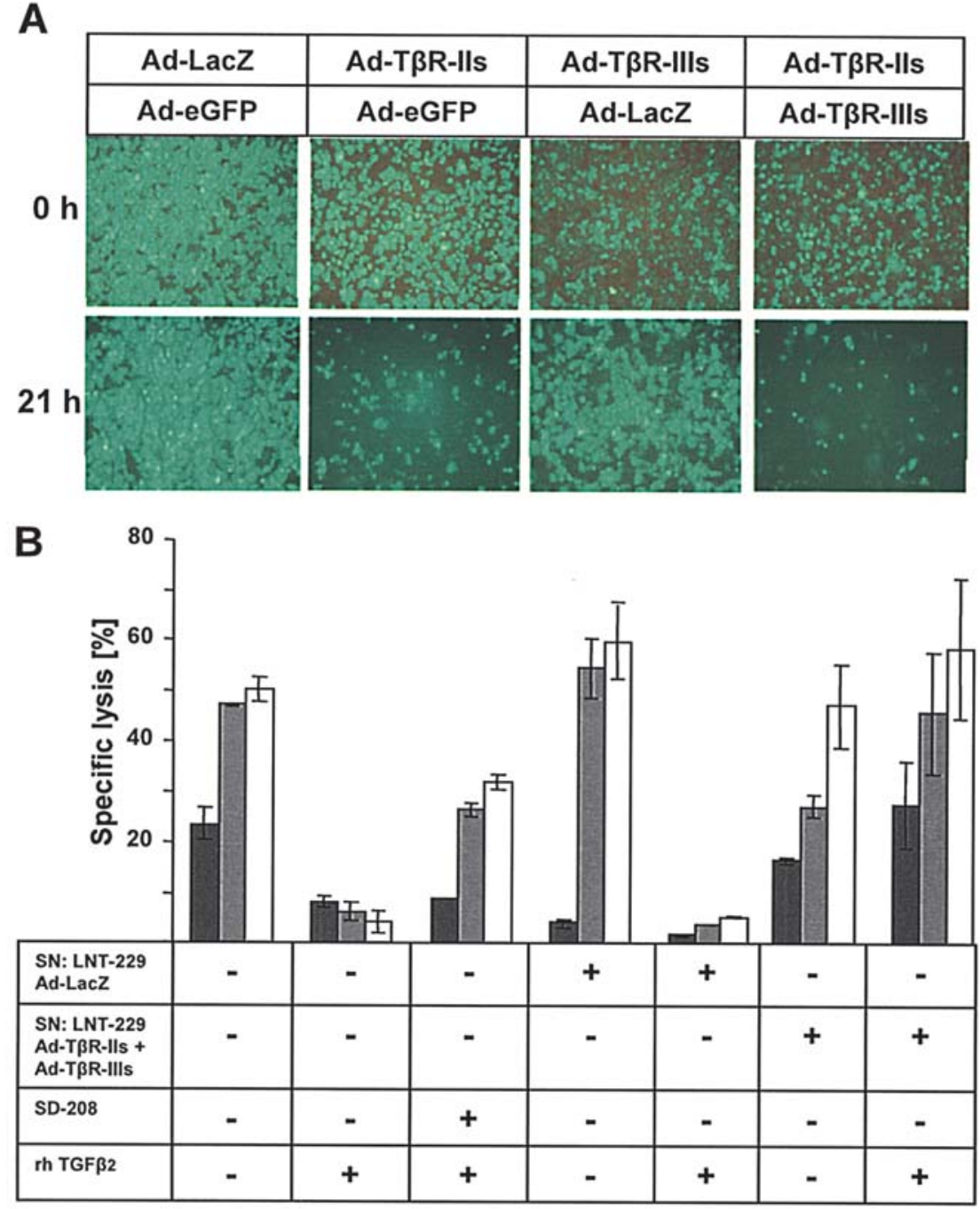

Figure 3. Expression of TßRs represses the inhibitory effects of TGF- $\beta$ on the lytic activity of NK cells. (A) LN-308 glioma cells were infected with 150 MOI of the indicated viruses for $24 \mathrm{~h}$ and then irradiated with $30 \mathrm{~Gy}$. After irradiation, human NK cells were added. Lysis of eGFP-positive glioma cells was assessed microscopically $24 \mathrm{~h}$ after coculture. (B) Supernatants of infected LNT-229 glioma cells (400 MOI Ad-LacZ or 200 MOI Ad-TßR-IIs + 200 MOI Ad-TßR-IIIs) were coincubated with rhTGFB $\beta_{2}$ for $30 \mathrm{~min}$ and then added to human NK cells. After $24 \mathrm{~h}$ of incubation, the NK cells were used as effectors in a ${ }^{51} \mathrm{Cr}$ release assay with untreated LNT-229 glioma cells as targets at different E:T ratios (dark gray bars 10:1; light gray bars 20:1; white bars 40:1). (n=3, SD, one representative experiment is shown).

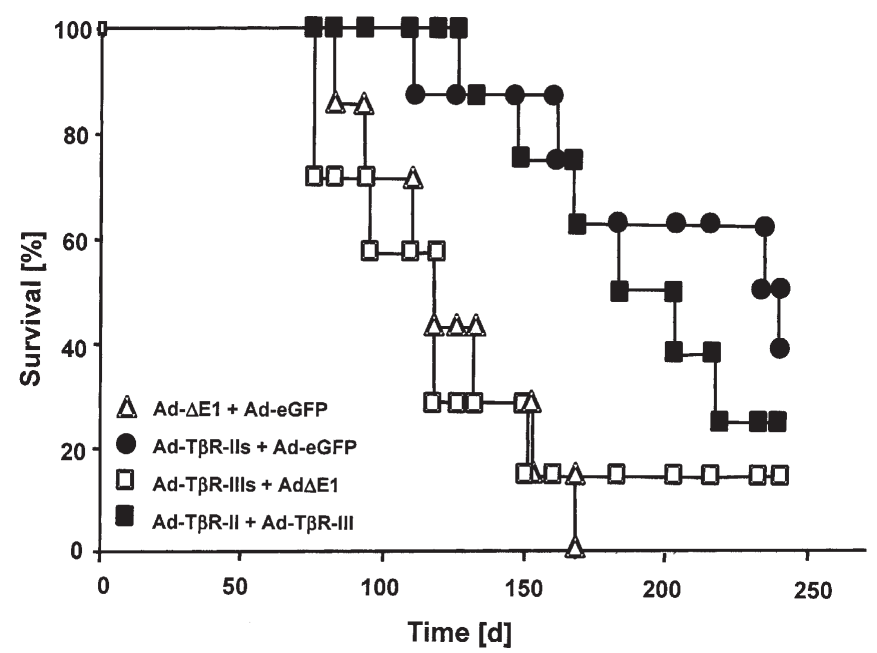

Figure 4. Expression TßR-IIs prolongs the survival of tumor-bearing mice. LN-308 cells were infected with 150 MOI of each virus. At $6 \mathrm{~h}$ after infection, 100,000 cells were inoculated into the right striatum of nude mice. Survival was assessed in a Kaplan-Meier-analysis. different efficacy in counteracting the biological effects of TGF- 3 . TßR-IIs inhibited activation of the TGF- 3 -signaling cascade when applied alone. In contrast, TßR-IIIs only showed activity when applied in combination with TßR-IIs (Fig. 2A and B). Moreover, the combination of TßR-IIs and -IIIs showed a synergistic functional activity in vitro (Fig. 2). Therefore, at least in combination, TßR-IIIs showed functional activity. Nevertheless, it remains unclear why TßR-IIIs were inactive when exposed alone, even though the expression was confirmed by immunoblotting. The synergistic action with TßR-IIs argues against the idea that the expression level was too low. One could hypothesize that TßR-IIIs only act together with TßR-IIs which possibly leads to a stabilized binding of TGF- $\beta$ in a complex with both TßRs. TßR-III or betaglycan is known to mediate TGF- $\beta$ binding to the TßR-II under physiological conditions on the cell surface (6). Therefore, TßR-IIIs might also act as an enhancer of TGF- $\beta$ interception. Consistent with the in vitro data, TßR-IIIs alone showed no significant effect in vivo. Unlike the in vitro results, the combination of TßR-IIs and TßR-IIIs showed no 
superior prolongation of survival compared to TßR-IIs alone. This might be dependent on the cell line, the mouse model and the single administration cycle used in this experiment.

The binding affinities of recombinant TßR-IIIs were different for the distinct TGF- $\beta$ isoforms (20). Therefore the function of the TBR-IIIs might be dependent on the relative quantities of the TGF- $\beta$ isoforms. The LN-308 tumors showed a rather slow progression in this xenogeneic tumor model. Nevertheless, the use of LN-308 appeared to be feasible and might be an alternative to the LNT-229 or U87MG model with the specific feature of slow tumor progression.

The in vitro data commend TßRs as an immunotherapeutic tool. NK cells and other immune effector cells are impaired by TGF-ß (21). The lytic functions of NK cells were restored by TßRs (Fig. 3). Again, the action of TßR-IIs was superior to that of TßR-IIIs, and the combination of both showed the best results (Fig. 3B). Witham et al used a retroviral vector coding for a truncated form of TßR-II and the rat gliosarcoma model 9L (15). In this paradigm, transduction of 9L cells led to reduced tumorigenicity in a subcutaneous model and enhanced survival after intracerebral inoculation. These effects were shown to be immuno-mediated and dependent on NK cell function. In our research we used an adenovirus instead of a retroviral vector and human glioma cell lines instead of a rat gliosarcoma cell line. Moreover, we investigated for the first time possible synergisms of TßR-IIs and -IIIs in antagonizing TGF- $\beta$ effects in the glioma context.

Taken together, adenovirally encoded TßRs can be used for future immunotherapy of gliomas. A major problem remains the route and mode of administration of a possible therapeutic agent to brain tumors. For TßRs, adenoviral gene transfer in a locoregional treatment is feasible. Further studies should also investigate alternative applications such as the use of DNA encoding for TßRs which has shown to be effective in a mouse lymphoma model (22). There are also efforts underway to enhance the antagonistic potency of TBRs by generation of homodimers or heterodimers of TßR-IIs and TßR-IIIs (23). This concept remains to be proven in animal cancer models. A lifelong antagonism of TGF- $\beta$ would be desirable in cancer patients. While some argue that chronic TGF-ß-antagonizing strategies may have serious side effects, it is noteworthy that in one study lifetime exposure to TßRs protected mice against metastasis without adverse side effects (24).

One future trend might be the use of an oncolytic virus containing an expression cassette for TßRs. This combines the virtue of an oncolytic virus to replicate exclusively in glioma cells and to follow invading glioma cells with the immune therapeutic effects of TßRs. Such an attempt has been used in a breast cancer model with promising results for further investigation (25).

\section{References}

1. Wick W, Naumann U and Weller M: Transforming growth factor-beta: A molecular target for the future therapy of glioblastoma. Curr Pharm Des 12: 341-349, 2006.

2. Eisele G, Wischhusen J, Mittelbronn M, Meyermann R, Waldhauer I, Steinle A, Weller M and Friese MA: TGF-beta and metalloproteinases differentially suppress NKG2D ligand surface expression on malignant glioma cells. Brain 129: 2416-2425, 2006.
3. Platten M, Wick W and Weller M: Malignant glioma biology: Role for TGF-beta in growth, motility, angiogenesis, and immune escape. Microsc Res Tech 52: 401-410, 2001.

4. Kawataki T, Naganuma H, Sasaki A, Yoshikawa H, Tasaka K and Nukui H: Correlation of thrombospondin-1 and transforming growth factor-beta expression with malignancy of glioma. Neuropathology 20: 161-169, 2000.

5. Kjellman C, Olofsson SP, Hansson O, Von Schantz T, Lindvall M, Nilsson I, Salford LG, Sjogren HO and Widegren B: Expression of TGF-beta isoforms, TGF-beta receptors, and SMAD molecules at different stages of human glioma. Int J Cancer 89: 251-258, 2000.

6. Shi Y and Massague J: Mechanisms of TGF-beta signaling from cell membrane to the nucleus. Cell 113: 685-700, 2003.

7. Esparza-Lopez J, Montiel JL, Vilchis-Landeros MM, Okadome T, Miyazono K and Lopez-Casillas F: Ligand binding and functional properties of betaglycan, a co-receptor of the transforming growth factor-beta superfamily. Specialized binding regions for transforming growth factor-beta and inhibin a. J Biol Chem 276: 14588-14596, 2001

8. Derynck R, Akhurst RJ and Balmain A: TGF-beta signaling in tumor suppression and cancer progression. Nat Genet 29: 117-129, 2001.

9. Uhl M, Aulwurm S, Wischhusen J, Weiler M, Ma JY, Almirez R, Mangadu R, Liu YW, Platten M, Herrlinger U, Murphy A, Wong DH, Wick W, Higgins LS and Weller M: SD-208, a novel transforming growth factor beta receptor I kinase inhibitor, inhibits growth and invasiveness and enhances immunogenicity of murine and human glioma cells in vitro and in vivo. Cancer Res 64: 7954-7961, 2004.

10. Fakhrai H, Dorigo O, Shawler DL, Lin H, Mercola D, Black KL, Royston I and Sobol RE: Eradication of established intracranial rat gliomas by transforming growth factor beta antisense gene therapy. Proc Natl Acad Sci USA 93: 2909-2914, 1996.

11. Rowland-Goldsmith MA, Maruyama H, Matsuda K, Idezawa T, Ralli M, Ralli S and Korc M: Soluble type II transforming growth factor-beta receptor attenuates expression of metastasis-associated genes and suppresses pancreatic cancer cell metastasis. Mol Cancer Ther 1: 161-167, 2002.

12. Suzuki E, Kapoor V, Cheung HK, Ling LE, DeLong PA, Kaiser LR and Albelda SM: Soluble type II transforming growth factor-beta receptor inhibits established murine malignant mesothelioma tumor growth by augmenting host antitumor immunity. Clin Cancer Res 10: 5907-5918, 2004.

13. Bandyopadhyay A, Lopez-Casillas F, Malik SN, Montiel JL, Mendoza V, Yang J and Sun LZ: Antitumor activity of a recombinant soluble betaglycan in human breast cancer xenograft. Cancer Res 62: 4690-4695, 2002.

14. Bandyopadhyay A, Wang L, Lopez-Casillas F, Mendoza V, Yeh IT and Sun L: Systemic administration of a soluble betaglycan suppresses tumor growth, angiogenesis, and matrix metalloproteinase- 9 expression in a human xenograft model of prostate cancer. Prostate 63: 81-90, 2005.

15. Witham TF, Villa L, Yang T, Pollack IF, Okada H, Robbins PD and Chambers WH: Expression of a soluble transforming growth factor-beta (TGF beta) receptor reduces tumorigenicity by regulating natural killer (NK) cell activity against 9L gliosarcoma in vivo. J Neurooncol 64: 63-69, 2003.

16. Naumann U, Kügler S, Wolburg H, Wick W, Rascher G, Schulz JB, Conseiller E, Bähr M and Weller M: Chimeric tumor suppressor 1, a p53-derived chimeric tumor suppressor gene, kills p53 mutant and p53 wild-type glioma cells in synergy with irradiation and CD95 ligand. Cancer Res 61: 5833-5842, 2001.

17. Ueno H, Sakamoto T, Nakamura T, Qi Z, Astuchi N, Takeshita A, Shimizu K and Ohashi H: A soluble transforming growth factor beta receptor expressed in muscle prevents liver fibrogenesis and dysfunction in rats. Hum Gene Ther 11: 33-42, 2000.

18. Moren A, Ichijo H and Miyazono K: Molecular cloning and characterization of the human and porcine transforming growth factor-beta type III receptors. Biochem Biophys Res Commun 189: 356-362, 1992

19. He TC, Zhou S, da Costa LT, Yu J, Kinzler KW and Vogelstein B: A simplified system for generating recombinant adenoviruses. Proc Natl Acad Sci USA 95: 2509-2514, 1998.

20. Vilchis-Landeros MM, Montiel JL, Mendoza V, MendozaHernandez G and Lopez-Casillas F: Recombinant soluble betaglycan is a potent and isoform-selective transforming growth factor-beta neutralizing agent. Biochem J 355: 215-222, 2001. 
21. Li MO, Wan YY, Sanjabi S, Robertson AK and Flavell RA: Transforming growth factor-beta regulation of immune responses. Annu Rev Immunol 24: 99-146, 2006.

22. Kontani K, Kajino K, Huangi CL, Fujino S, Taguchi O, Yamauchi A, Yokomise $\mathrm{H}$ and Ogasawara K: Spontaneous elicitation of potent antitumor immunity and eradication of established tumors by administration of DNA encoding soluble transforming growth factor-beta II receptor without active antigen-sensitization. Cancer Immunol Immunother 55: 579-587, 2006.

23. De Crescenzo G, Pham PL, Durocher Y, Chao H and O'Connor-McCourt MD: Enhancement of the antagonistic potency of transforming growth factor-beta receptor extracellular domains by coiled coil-induced homo- and heterodimerization. J Biol Chem 279: 26013-26018, 2004.
24. Yang YA, Dukhanina O, Tang B, Mamura M, Letterio JJ, MacGregor J, Patel SC, Khozin S, Liu ZY, Green J, Anver MR, Merlino G and Wakefield LM: Lifetime exposure to a soluble TGF-beta antagonist protects mice against metastasis without adverse side effects. J Clin Invest 109: 1607-1615, 2002.

25. Seth P, Wang ZG, Pister A, Zafar MB, Kim S, Guise T and Wakefield L: Development of oncolytic adenovirus armed with a fusion of soluble transforming growth factor-beta receptor II and human immunoglobulin Fc for breast cancer therapy. Hum Gene Ther 17: 1152-1160, 2006. 